Review

\title{
Polymer Electrolytes for Lithium/Sulfur Batteries
}

\section{Yan Zhao, Yongguang Zhang, Denise Gosselink, The Nam Long Doan, Mikhail Sadhu, Ho-Jae Cheang and Pu Chen *}

Department of Chemical Engineering, University of Waterloo, 200 University Avenue West, Waterloo, Ontario N2L3G1, Canada; E-Mails: y236zhao@uwaterloo.ca (Y.Z.); y378zhan@uwaterloo.ca (Y.Z.); denise@uwaterloo.ca (D.G.); doannamlong@yahoo.com (T.N.L.D.); mikhailsadhu@hotmail.com (M.S.); hcheang@uwaterloo.ca (H.-J.C.)

* Author to whom correspondence should be addressed; E-Mail: p4chen@ uwaterloo.ca; Tel.: +1-519-888-4567 ext. 35586; Fax: +1-519-746-4979.

Received: 9 May 2012; in revised form: 16 July 2012 / Accepted: 17 July 2012 /

Published:

\begin{abstract}
This review evaluates the characteristics and advantages of employing polymer electrolytes in lithium/sulfur (Li/S) batteries. The main highlights of this study constitute detailed information on the advanced developments for solid polymer electrolytes and gel polymer electrolytes, used in the lithium/sulfur battery. This includes an in-depth analysis conducted on the preparation and electrochemical characteristics of the $\mathrm{Li} / \mathrm{S}$ batteries based on these polymer electrolytes.
\end{abstract}

Keywords: polymer electrolyte; lithium-sulfur battery; solid polymer electrolyte; gel polymer electrolyte

\section{Introduction}

With the rapid exhaustion of limited resources such as fossil fuels and their global environmental issues, the modern society's sustainability depends on the development of ecological alternative power sources such as solar and wind energy, and low-emission transportation such as hybrid and electric vehicles. High energy-density batteries are an essential part of such systems and there is an insatiable demand for its improvement. Secondary lithium-ion batteries (LIBs) dominate the market for portable electronics (e.g., cellular phones, notebook computers, camcorders) [1-3], but are still not economically attractive for large scale and transportation applications. 
Although tremendous progress has been achieved in the field of LIBs, the transition metal oxides and phosphates typically used as cathode materials have maximum theoretical capacity limited to about $200 \mathrm{mAh} \cdot \mathrm{g}^{-1}$ (of which only $170 \mathrm{mAh} \cdot \mathrm{g}^{-1}$ can be practically achieved) [4-7]. The energy limitations, along with the high cost and ecological concerns of these materials, can restrict their practical application in large scale scenarios.

An alternative technology under intense development is the lithium/sulfur battery $(\mathrm{Li} / \mathrm{S})$. Elemental sulfur has higher theoretical capacity $\left(1672 \mathrm{mAh} \cdot \mathrm{g}^{-1}\right)$ and specific energy $\left(2600 \mathrm{Wh} \cdot \mathrm{kg}^{-1}\right)$ than conventional cathode materials. Sulfur is also a low cost, abundant, and environmentally friendly natural resource [8], making it a very promising cathode material candidate, especially for large scale energy storage applications [9]. However, Li/S batteries suffer from inefficient utilization of cathode materials and poor cyclability $[9,10]$, both essentially due to the insulating nature of $S$ and the solubility of polysulfides in liquid organic electrolytes [11-14].

Successful operation of $\mathrm{Li} / \mathrm{S}$ batteries has been achieved through the development of composites of sulfur with carbonaceous [5,15-23] and polymeric [24-27] materials. In these composites, the S particles are embedded into the conductive carbon or polymer matrices [5,21,28], which enhance the electronic conductivity of the composite and hinder the dissolution of polysulfides into the electrolyte $[13,14,28-30]$.

Another strategy to improve the capacity and cyclability of $\mathrm{Li} / \mathrm{S}$ batteries is the electrolyte optimization so as to reduce the loss of sulfur by dissolution in the liquid electrolyte [14,31-35]. Among the possible electrolyte modifications, replacement of the common liquid organic electrolytes with polymer electrolytes has proved promising and efficient.

Polymer electrolyte may generally be defined as a membrane that possesses transport properties comparable to that of common liquid ionic solutions [36]. Although the study of polymer electrolyte was started in 1973 by Fenton et al. [37], its technological importance was appreciated in the early 1980s [38]. Since then, a large number of polymer electrolyte systems have been prepared and characterized. It is possible and convenient to group all the polymer systems into two broad categories, i.e., pure solid polymer electrolyte (SPE) and plasticized or gel polymer electrolyte systems (GPE).

The first category, pure solid polymer electrolyte, is composed of lithium salts (e.g., $\mathrm{LiClO}_{4}, \mathrm{LiBF}_{4}$, $\left.\mathrm{LiPF}_{6}, \mathrm{LiAsF}_{6}, \mathrm{LiCF}_{3} \mathrm{SO}_{3}, \mathrm{LiN}\left(\mathrm{CF}_{3} \mathrm{SO}_{2}\right)_{2}, \mathrm{LiC}\left(\mathrm{CF}_{3} \mathrm{SO}_{2}\right)_{3}\right)$ dissolved in high molecular weight polyether hosts, (e.g., PEO and PPO) which acts as solid solvents [39]. The ionic conduction mechanism of SPE is intimately associated with the local segmental motions of the polymer. The second category of polymer electrolyte, gel polymer electrolyte, is characterized by a higher ambient ionic conductivity but poorer mechanical properties when compared with SPE. GPE is usually obtained by incorporating a larger quantity of liquid electrolyte to a polymer matrix that is capable of forming a stable gel polymer host structure.

Polymer electrolytes have several obvious advantages over their liquid electrolyte. Among the advantages of these electrolytes, they include no internal shorting, leakage of electrolytes and no non-combustible reaction products at the electrode surface existing in the liquid electrolytes [40-44]. The pre-requisites for a polymer electrolyte for lithium batteries are: high ionic conductivity at ambient and subambient temperatures, good mechanical strength, appreciable transference number, thermal and electrochemical stabilities, and better compatibility with electrodes $[41-43,45]$. In particular, for $\mathrm{Li} / \mathrm{S}$ battery, it is expected that the polymer membrane can act as a physical barrier, which can help control 
the dissolution of the sulfide anions from the cathode and also prevent the attack of the same anions at the anode [46].

Herein, this article does not intend to review the modification of cathodes or liquid electrolytes, but it focuses on the applications of polymer electrolytes in Li/S batteries. In this review, the preparation and electrochemical properties of polymer electrolytes are studied based on the catalogue of polymer electrolytes. The electrochemical characteristics of the $\mathrm{Li} / \mathrm{S}$ batteries based on these polymer electrolytes, related to the performance of their cells, are also discussed here.

\section{Dry Solid Polymer Electrolytes in Li/S Batteries}

In dry solid polymer electrolytes, the polymer host itself is used as a solid solvent along with lithium salt and it does not contain any organic liquids. As a polymer host, the high molecular weight poly(ethylene oxide) (PEO)-based solid polymer electrolytes are emerging as the best candidates to be used because of their solvation power, complexation ability and ion transport mechanism directly connected with the alkaline salt $\left(\mathrm{Li}^{+}\right)$. However, the ionic conductivity of PEO-lithium salts (LiX) electrolytes at ambient temperature $\left(10^{-7}-10^{-6} \mathrm{~S} \cdot \mathrm{cm}^{-1}\right)$ is not high enough for most practical applications. In order to overcome this problem, consistent research efforts have been devoted to improve the ionic conductivity of PEO-LiX $\left(\mathrm{X}=\mathrm{ClO}_{4}{ }^{-}, \mathrm{CF}_{3} \mathrm{SO}_{3}{ }^{-}, \mathrm{BF}_{4}{ }^{-}, \mathrm{PF}_{6}{ }^{-}\right.$, etc. $)$solid polymer electrolytes $[42,47]$.

In Jeon et al.'s study [48], $\mathrm{LiClO}_{4}$ was chosen to dissolve in high molecular weight polymer host-PEO which acted as solid solvents. Dry polymer electrolyte made of PEO with tetra(ethylene glycol dimethyl ether) was employed into Li/S cells to study issues such as the fading capacity and low sulfur utilization. According to the change in morphologies for a composite sulfur cathode, which was obtained by scanning electron microscopy (SEM), a model for the change in morphology of the composite cathode was built as shown in Figure 1. The authors offered us a mechanism for the capacity fading was mainly due to the heterogeneity and worsening distribution of sulfur along with cycling.

Some researchers have been trying to further improve the conductivity by the use of inorganic ceramic filler such as $\mathrm{Al}_{2} \mathrm{O}_{3}, \mathrm{SiO}_{2}, \mathrm{TiO}_{2}$ and $\mathrm{ZrO}_{2}$ in the host polymer matrix [49-57].

In Shin et al.'s study [58], (PEO) $)_{10} \mathrm{LiCF}_{3} \mathrm{SO}_{3}$ polymer electrolyte with titanium oxide $\left(\mathrm{Ti}_{n} \mathrm{O}_{2 n-1}\right.$, $n=1,2$ ) was introduced into Li/S system, and they not only investigated the ionic conductivity and interfacial stability of this dry polymer electrolyte but also the discharge characteristics of Li/S cells with $(\mathrm{PEO})_{10} \mathrm{LiCF}_{3} \mathrm{SO}_{3}$ polymer electrolyte. From the results of this study, titanium oxide is a good candidate as ceramic filler in $(\mathrm{PEO})_{10} \mathrm{LiCF}_{3} \mathrm{SO}_{3}$ dry polymer electrolyte. Titanium Oxide filler has a size of sub-micron and several micron consisting of various phases that were prepared by ball milling for $100 \mathrm{~h}$, which wereintroduced into the $(\mathrm{PEO})_{10} \mathrm{LiCF}_{3} \mathrm{SO}_{3}$ polymer electrolyte. The addition of titanium oxide containing $\mathrm{Ti}_{2} \mathrm{O}_{3}, \mathrm{TiO}$ and $\mathrm{Ti}_{2} \mathrm{O}$ into the $(\mathrm{PEO})_{10} \mathrm{LiCF}_{3} \mathrm{SO}_{3}$ polymer electrolyte improved the ionic conductivity due to the change of $-\mathrm{C}-\mathrm{O}-\mathrm{C}-$ vibration and ionic structure of polymer electrolyte by the decrease in crystallinity of PEO polymer electrolyte, and the interface resistance between polymer electrolyte and lithium electrode was remarkably decreased by lowering the contact area between lithium and electrolyte. 
Figure 1. Model for morphology change of composite cathode during charge-discharge: (a) ideal case; (b) real case [48].

(a)
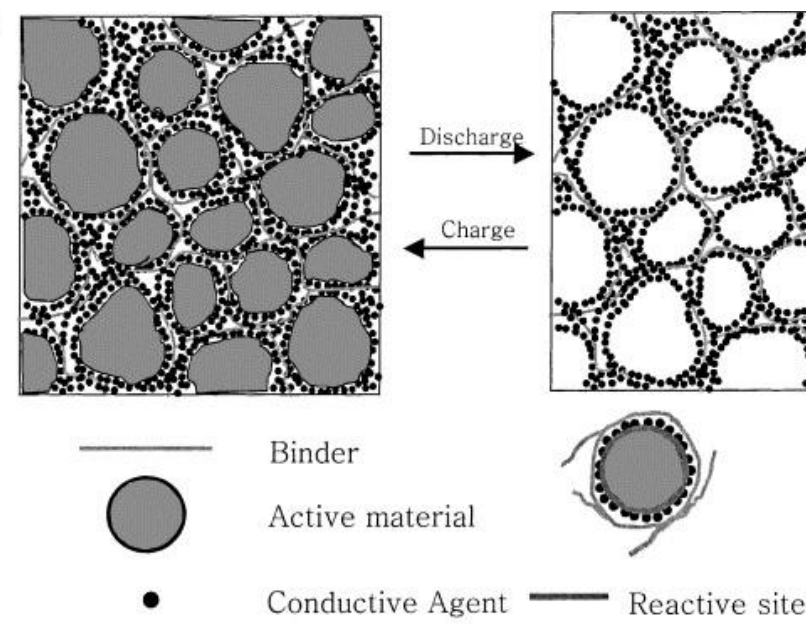

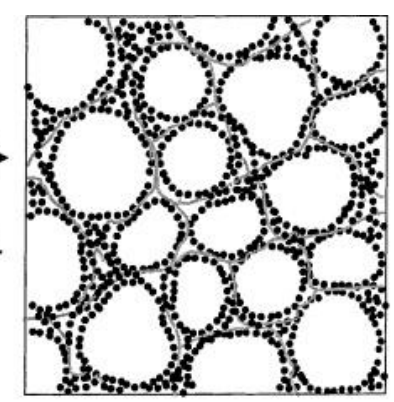

Reactive site

(b)

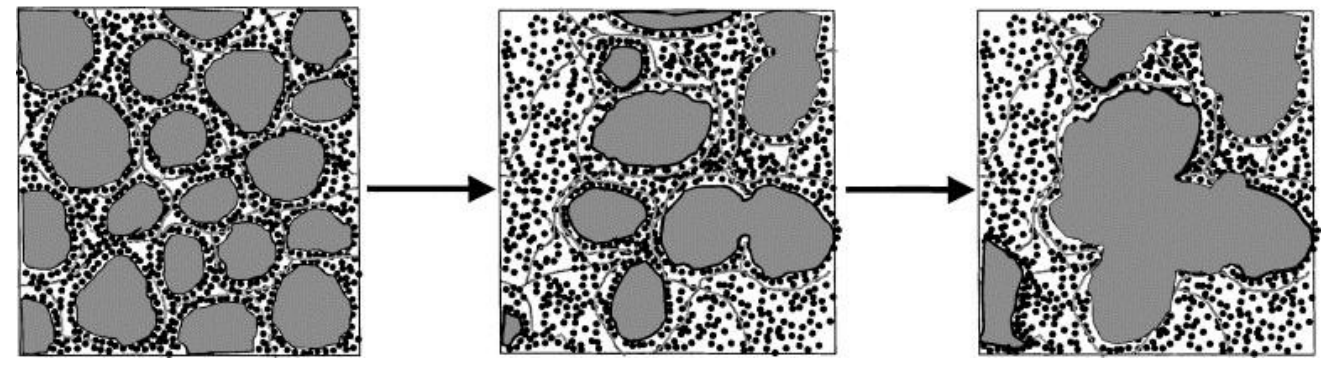

In Jeong et al.'s study [59], $(\mathrm{PEO})_{6} \mathrm{LiBF}_{4}$ polymer electrolyte was prepared under three different mixing conditions: stirred polymer electrolyte, ball-milled polymer electrolyte and ball-milled polymer electrolyte with 10 wt $\% \mathrm{Al}_{2} \mathrm{O}_{3}$. The $\mathrm{Li} / \mathrm{S}$ cell containing ball-milled $(\mathrm{PEO})_{6} \mathrm{LiBF}_{4}-\mathrm{Al}_{2} \mathrm{O}_{3}$ polymer electrolyte delivered a high initial discharge of $1670 \mathrm{mAh} \cdot \mathrm{g}^{-1}$, which was better than the cells with stirred $(\mathrm{PEO})_{6} \mathrm{LiBF}_{4}$ polymer electrolyte or $(\mathrm{PEO})_{6} \mathrm{LiBF}_{4}$ ball-milled polymer electrolyte. And also the cycle performance of $\mathrm{Li} /(\mathrm{PEO})_{6} \mathrm{LiBF}_{4} / \mathrm{S}$ cell was also remarkably improved with the addition of $\mathrm{Al}_{2} \mathrm{O}_{3}$.

$(\mathrm{PEO})_{20} \mathrm{Li}\left(\mathrm{CF}_{3} \mathrm{SO}_{2}\right)_{2} \mathrm{~N}-\gamma \mathrm{LiAlO}_{2}$ was prepared and introduced into $\mathrm{Li} / \mathrm{S}$ battery in Wen et al.'s study [60]. The all-solid-state $\mathrm{Li} / \mathrm{S}$ cell with PEO based polymer electrolyte operating at $75{ }^{\circ} \mathrm{C}$ exhibited an average capacity of $290 \mathrm{mAh} \cdot \mathrm{g}^{-1}$ in 50 cycles. The cycle-stability of Li/S polymer battery was improved by amending the method to prepare the sulfur composite cathode by blending sulfur and PEO by thermal melting at $180{ }^{\circ} \mathrm{C}$ in a sealed container. The SEM results confirmed the mechanism of capacity fading [48], which suggested that the capacity of Li/S polymer battery was mostly suffered from aggregation of sulfur or lithium sulfide during cycling.

This research group did a further study to combine $(\mathrm{PEO})_{18} \mathrm{Li}\left(\mathrm{CF}_{3} \mathrm{SO}_{2}\right)_{2} \mathrm{~N}-\mathrm{SiO}_{2}$ polymer electrolyte and sulfur/mesoporous-carbon composite cathode as an all solid state polymer battery [29]. The conductivity of the PEO based electrolyte could reach $5 \times 10^{-4} \mathrm{~S} \cdot \mathrm{cm}^{-1}$ at $70{ }^{\circ} \mathrm{C}$. In the sulfur cathode, mesoporous carbon sphere with the uniform channels was employed as the conductive agent, and sulfur was penetrated into those channels by a co-heating method. By this, the prepared all solid state polymer battery showed excellent cycling performance with a reversible discharge capacity of about $800 \mathrm{mAh} \cdot \mathrm{g}^{-1}$ at $70{ }^{\circ} \mathrm{C}$ after 25 cycles. 
In summary, the reason for the choosing PEO as the polymer host is mainly due to that PEO usually form stable dry complexes exhibiting a relatively higher ionic conductivity than other solvating polymers [61]. The sequential oxyethylene group: $-\mathrm{CH}_{2}-\mathrm{CH}_{2}-\mathrm{O}-$, and the polar groups: $-\mathrm{O}-,-\mathrm{H}-$, $-\mathrm{C}-\mathrm{H}-$, in the polymer chains can well dissolve the ionic salts $[43,44,62]$. In the further study, new polymer electrolyte structures, based on the modified PEO main polymer chain with grafted polymers, block copolymers, cross-linked polymer networks, which resulted in polymer electrolytes with a lower degree of crystallinity and a low glass transition temperature $T_{\mathrm{g}}$, can be considered to employed into $\mathrm{Li} / \mathrm{S}$ battery system.

\section{Gel Polymer Electrolytes in Li/S Batteries}

In the point of view of dry solid polymer, the main obstacle is still the ionic conductivity, which is generally below $10^{-3} \mathrm{~S} \cdot \mathrm{cm}^{-1}$ and not enough for practical application. At room temperature, the all solid state Li/S batteries usually showed poor performance. As a result, gel polymer electrolytes were developed [63-65], which can be regarded as an intermediate state between typical liquid electrolytes and dry solid polymer electrolytes. In gel polymer electrolytes, the liquid component is trapped in the polymer matrix, thereby preventing leakage of liquid electrolyte. Therefore, the pore structure of the polymer membrane is the key component and is especially important for the ionic conductivity. In Li/S battery, to date, several types of polymer membranes have been developed and characterized, such as those based on poly(ethylene oxide) (PEO), poly(vinylidene fluoride) (PVDF) and poly(vinylidene fluoride)-hexafluoropropylene (PVDF-HFP).

\subsection{PEO-Based Gel Polymer Electrolyte}

Important progress was recently made by Scrosati and co-workers [66], who built a lithium metal-free new battery version as Figure 2 shows. They also renewed the electrolyte component by replacing the common liquid organic solutions with a gel-type polymer membrane, formed by trapping ethylene carbonate/dimethylcarbonate lithium hexafluorophosphate $\left(\mathrm{EC}: \mathrm{DMC}_{\mathrm{LiPF}}\right)$ solution saturated with lithium sulfide in a polyethylene oxide/lithium trifluoromethanesulfonate $\left(\mathrm{PEO} / \mathrm{LiCF}_{3} \mathrm{SO}_{3}\right)$ polymer matrix [67]. A dispersed zirconia ceramic filler enhanced the mechanical properties of the gel and improved liquid retention within its bulk [68]. Impedance studies [69] indicate that the resistance of the as-prepared GPE is low and stable with time with a high conductivity approaching $10^{-2} \mathrm{~S} \cdot \mathrm{cm}^{-1}$ (Figure 3). With the assembly of the $\mathrm{Sn} / \mathrm{C}$ anode, $\mathrm{Li}_{2} \mathrm{~S} / \mathrm{C}$ cathode and PEO based GPE, this polymer battery showed a high initial discharge of about $1200 \mathrm{mAh} \cdot \mathrm{g}^{-1}$ at $38 \mathrm{~mA} \cdot \mathrm{cm}^{-2} \cdot \mathrm{g}^{-1}$ (capacity calculated based on $\mathrm{Li}_{2} \mathrm{~S}$ mass only). 
Figure 2. Sketch of the $\mathrm{Sn} / \mathrm{C} / \mathrm{CGPE} / \mathrm{Li}_{2} \mathrm{~S} / \mathrm{C}$ polymer battery developed herein. The battery is formed by a $\mathrm{Sn} / \mathrm{C}$ composite anode, a PEO based gel polymer electrolyte, and a $\mathrm{Li}_{2} \mathrm{~S} / \mathrm{C}$ cathode. $\mathrm{PEO}=$ poly (ethylene oxide) [66].

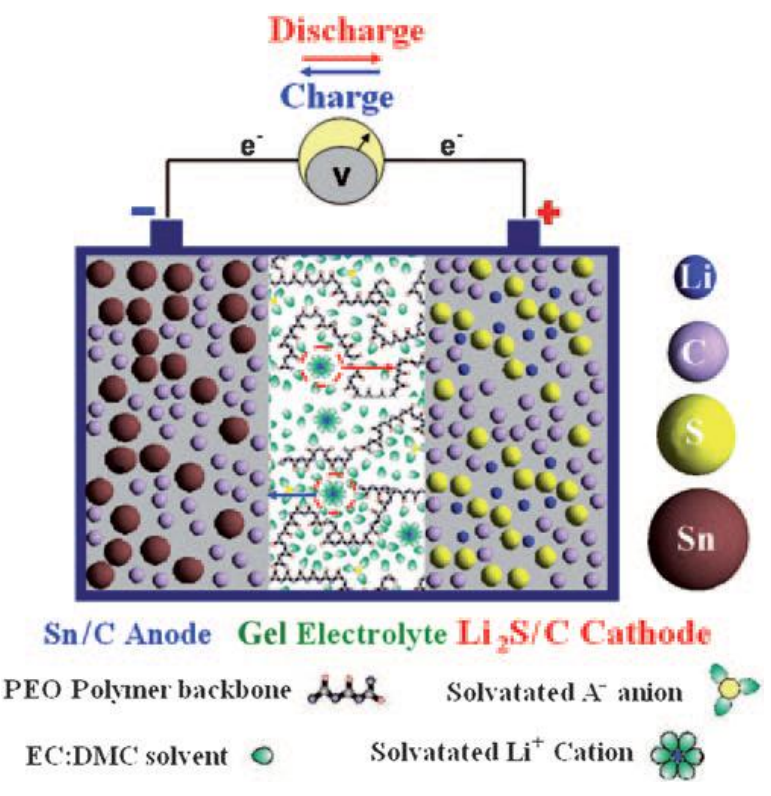

Figure 3. Characteristics of the PEO based gel polymer membrane to be used as electrolyte separator in the lithium-sulfur battery: (a) Appearance of the membrane; (b) Time evolution of the conductivity at room temperature [66].
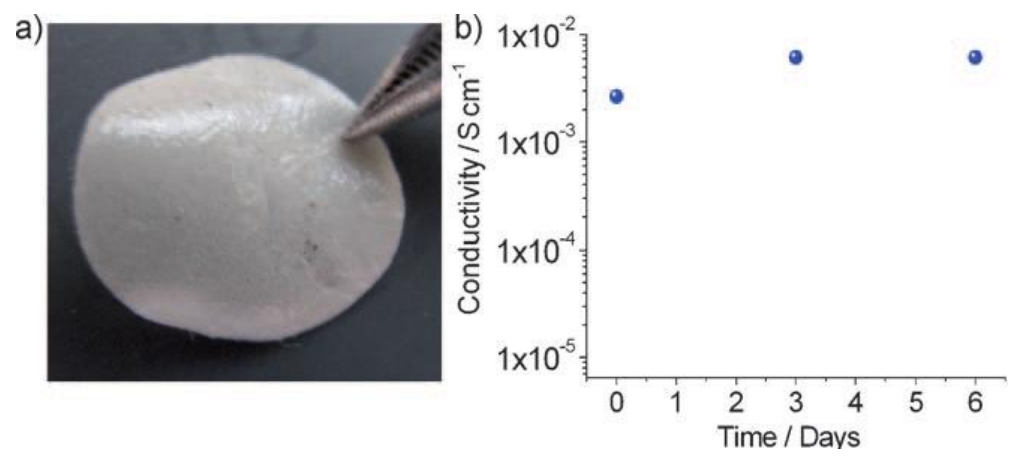

\subsection{PVDF-Based Gel Polymer Electrolyte}

Poly(vinylidene fluoride) (PVDF) has received great attention as a membrane material with regard to its outstanding properties such as high mechanical strength, thermal stability, chemical resistance, and high hydrophobicity [70]. By virtue of its various appealing properties, PVDF has been chosen as a suitable polymer host. PVDF-based polymer electrolytes are expected to be highly anodically stable due to the strongly electron-withdrawing functional group $(-\mathrm{C}-\mathrm{F})$. Furthermore, PVDF itself has a high dielectric constant $(\varepsilon=8.4)$ for a polymer, which can assist in greater ionization of lithium salts, and thus provide a high concentration of charge carriers [39,71].

A detailed discussion regarding the discharge process of $\mathrm{Li} / \mathrm{PVDF} / \mathrm{S}$ was presented by Ryu et al. [72]. The PVDF gel polymer electrolyte was prepared by $\mathrm{LiCF}_{3} \mathrm{SO}_{3}$ as lithium-ion resource, tetraglyme as plasticizer, and PVDF as a gelling agent in THF solvent in Ar atmosphere. A freestanding PVDF electrolyte film was obtained after the solvent was evaporated at room 
temperature. By using PVDF polymer electrolyte, the $\mathrm{Li} / \mathrm{S}$ cell had two plateaus-like potential regions and a discharge capacity of $1268 \mathrm{mAh} \cdot \mathrm{g}^{-1}$ at the first discharge. The discharge capacity decreased to $1028 \mathrm{mAh} \cdot \mathrm{g}^{-1}$ and the upper plateau region disappeared after second discharge. From XRD and DSC results of the sulfur electrode, a model was built as shown in Figure 4 to suggest that elemental sulfur disappeared and changed into $\mathrm{Li}_{2} \mathrm{~S}_{\mathrm{n}}(n>4)$ at the upper plateau region and $\mathrm{Li}_{2} \mathrm{~S}$ was formed at the low plateau region.

Figure 4. The discharge and charge reaction model of lithium/sulfur cell [72].

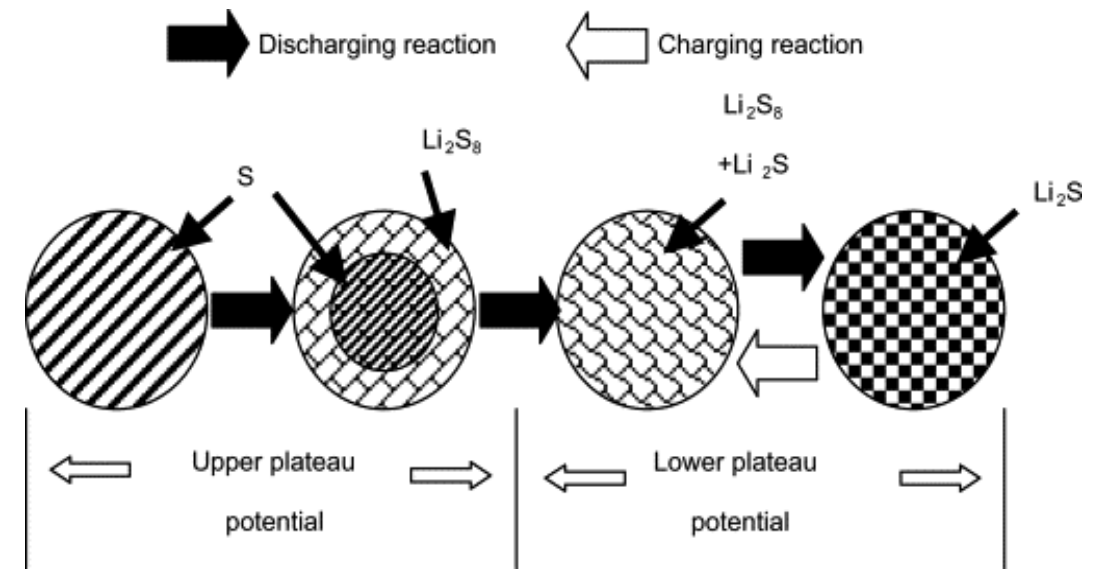

\subsection{PVDF-HFP Based Gel Polymer Electrolyte}

Poly(vinylidene fluoride)-hexafluoropropylene (PVDF-HFP) has drawn the attention of many researchers due to its appealing properties. The high dielectric constant of $\varepsilon=8.4$ facilitates for higher concentration of charge carriers, and it also comprises of both amorphous and crystalline phase; the amorphous phase of the polymer helps for higher ionic conduction, whereas the crystalline phase acts as a mechanical support for the polymer electrolyte [73-75].

Shin et al. [76] reported the preparation and performance of PVDF-HFP gel electrolyte in Li/S batteries. The PVDF-HFP gel polymer electrolyte with tetra ethylene glycol dimethylether (TEGDME) as a plasticizer, $\mathrm{LiCF}_{3} \mathrm{SO}_{3}, \mathrm{LiBF}_{4}$ and $\mathrm{LiPF}_{6}$ as lithium salt and acetone as solvent was prepared by solvent casting of slurry that mixed PVDF-HFP copolymer with acetone and salt using a ball-milling technique. This polymer electrolyte showed high mechanical property and good ionic conductivity $\left(4.99 \times 10^{-4} \mathrm{~S} \cdot \mathrm{cm}^{-1}\right.$ at room temperature $)$. As ball-milled gel polymer electrolytes were introduced into $\mathrm{Li} / \mathrm{S}$ cells with sulfur as cathode and lithium as the anode. The first specific discharge capacities with discharge rate of $0.14 \mathrm{~mA} \cdot \mathrm{cm}^{-2}$ at room temperature were about 575 and $765 \mathrm{mAh} \cdot \mathrm{g}^{-1}$. The melting temperature of crystalline PVDF-HFP was found to decrease, which may be due to the decrease of crystallinity by scission of the polymer chain during ball milling. Therefore, it was concluded that the ball-milling technique could be a very promising preparative technique for the preparation of slurry for polymer electrolytes.

In Wang et al's study [15,24], a gel polymer electrolyte was formed by trapping a liquid electrolyte of PC-EC-DEC (1:4:5 v/v) containing $1 \mathrm{M} \mathrm{LiPF}_{6}$ in a dry PVDF-HFP/SiO 2 polymer matrix. And this dry PVDF-HFP/SiO $/ \mathrm{S}_{2}$ film with abundant pore structure was prepared by phase separation method. The ionic conductivity of resulting gel polymer electrolyte was about $1.2 \times 10^{-3} \mathrm{~S} \cdot \mathrm{cm}^{-1}$ at room 
temperature. This gel polymer electrolyte was introduced into the cells with sulfur/active carbon composite cathode and sulfur/polyacrylonitrile (S/PAN) composite, respectively. The cell with S/PAN composite cathode exhibited a specific capacity up to $850 \mathrm{~mA} \cdot \mathrm{g}^{-1}$ in the initial and remained above $600 \mathrm{mAh} \cdot \mathrm{g}^{-1}$ after 50 cycles. With elemental sulfur incorporated in porous carbon, S/C composite exhibited reversible capacity of $440 \mathrm{mAh} \cdot \mathrm{g}^{-1}$ at current density of $0.3 \mathrm{~mA} \cdot \mathrm{cm}^{-2}$.

In summary, gel polymer electrolyte was considered as liquid electrolyte trapped in the polymer membrane. When the bulk of the membrane was composed of connected micropores, the ion conductivity of the gel polymer electrolyte mainly depended on the property of the liquid electrolyte. Otherwise, if the prepared membrane did not have many connected pores, the transfer of $\mathrm{Li}^{+}$mainly happens in the polymer membrane [77]. Therefore, in the further study, modifying the pore structure of the membrane and changing the crystallinity of the polymer matrix were developed as the most important strategies to improve $\mathrm{Li}^{+}$transport and ion conductivity of GPE in $\mathrm{Li} / \mathrm{S}$ battery . The former was mainly achieved by optimizing the preparation methods and the latter by modifications of polymer matrix, such as blending, copolymer and cross-linking, compounding, and adding nanofillers [77].

\section{Conclusions}

$\mathrm{Li} / \mathrm{S}$ batteries provide much hope, but also many challenges. In general, the main problem in an $\mathrm{Li} / \mathrm{S}$ battery is its poor cyclic ability, which is mainly caused by polysulfides dissolving into the electrolyte. To solve this problem, the polymer electrolyte is introduced into Li/S battery. As discussed above, with employment of a dry polymer electrolyte and gel polymer electrolyte, the cell showed a better cycle performance. However, problems in Li/S batteries, such as aggregation of sulfur or lithium sulfide during cycling, could not be solved merely by modifying the electrolyte. Together with advances in anodes and cathodes, the development of polymer electrolytes with high conductivity, high compatibility and mechanical strength, can offer a promising future for Li/S batteries.

\section{Acknowledgments}

This research was financially supported by Positec, the Natural Sciences and Engineering Research Council of Canada (NSERC), Canadian Foundation for Innovation (CFI) and the Canada Research Chairs (CRC) program. One of the authors (YZ) thanks the China Scholarship Council for Study Abroad Scholarship.

\section{References}

1. Song, D.; Ikuta, H.; Uchida, T.; Wakihara, M. The spinel phases $\operatorname{LiAl}_{y} \mathrm{Mn}_{2-y} \mathrm{O}_{4}(y=0,1 / 12,1 / 9$, $1 / 6,1 / 3)$ and $\mathrm{Li}(\mathrm{Al}, \mathrm{M})_{1 / 6} \mathrm{Mn}_{11 / 6} \mathrm{O}_{4}(\mathrm{M}=\mathrm{Cr}, \mathrm{Co})$ as the cathode for rechargeable lithium batteries. Solid State Ionics 1999, 117, 151-156.

2. Bakenov, Z.; Taniguchi, I. Electrochemical performance of nanostructured $\mathrm{LiM}_{x} \mathrm{Mn}_{2-x} \mathrm{O}_{4}(\mathrm{M}=\mathrm{Co}$ and Al) powders at high charge-discharge operations. Solid State Ionics 2005, 176, 1027-1034.

3. Kang, B.; Ceder, G. Battery materials for ultrafast charging and discharging. Nature 2009, 458, 190-193.

4. Whittingham, M.S. Lithium batteries and cathode materials. Chem. Rev. 2004, 104, 4271-4302. 
5. Ji, X.L.; Lee, K.T.; Nazar, L.F. A highly ordered nanostructured carbon-sulphur cathode for lithium-sulphur batteries. Nat. Mater. 2009, 8, 500-506.

6. Sun, Y.K.; Myung, S.T.; Park, B.C.; Prakash, J.; Belharouak, I.; Amine, K. High-energy cathode material for long-life and safe lithium batteries. Nat. Mater. 2009, 8, 320-324.

7. Yang, Y.; McDowell, M.T.; Jackson, A.; Cha, J.J.; Hong, S.S.; Cui, Y. New nanostructured $\mathrm{Li}_{2} \mathrm{~S} /$ silicon rechargeable battery with high specific energy. Nano Lett. 2010, 10, 1486-1491.

8. Tischer, R.P. The Sulfur Electrode; Academic Press: New York, NY, USA, 1983.

9. Marmorstein, D.; Yu, T.H.; Striebel, K.A.; McLarnon, F.R.; Hou, J.; Cairns, E.J. Electrochemical performance of lithium/sulfur cells with three different polymer electrolytes. J. Power Sources 2000, 89, 219-226.

10. Yamin, H.; Peled, E. Electrochemistry of a nonaqueous lithium/sulfur cell. J. Power Sources 1983, 9, 281-287.

11. Rauh, R.D.; Abraham, K.M.; Pearson, G.F.; Surprenant, J.K.; Brummer, S.B. A lithium/dissolved sulfur battery with an organic electrolyte. J. Electrochem. Soc. 1979, 126, 523-527.

12. Yamin, H.; Gorenshtein, A.; Penciner, J.; Sternberg, Y.; Peled, E. Lithium sulfur battery. J. Electrochem. Soc. 1988, 135, 1045-1048.

13. Shim, J.; Striebel, K.A.; Cairns, E.J. The lithium/sulfur rechargeable cell. J. Electrochem. Soc. 2002, 149, A1321-A1325.

14. Cheon, S.E.; Ko, K.S.; Cho, J.H.; Kim, S.W.; Chin, E.Y.; Kim, H.T. Rechargeable lithium sulfur battery. J. Electrochem. Soc. 2003, 150, A796-A799.

15. Wang, J.L.; Yang, J.; Xie, J.Y.; Xu, N.X.; Li, Y. Sulfur-carbon nano-composite as cathode for rechargeable lithium battery based on gel electrolyte. Electrochem. Commun. 2002, 4, 499-502.

16. Han, S.C.; Song, M.S.; Lee, H.; Kim, H.S.; Ahn, H.J.; Lee, J.Y. Effect of multiwalled carbon nanotubes on electrochemical properties of lithium/sulfur rechargeable batteries. J. Electrochem. Soc. 2003, 150, A889-A893.

17. Zheng, W.; Liu, Y.W.; Hu, X.G.; Zhang, C.F. Novel Nanosized Adsorbing Sulfur Composite Cathode Materials for the Advanced Secondary Lithium Batteries. Electrochim. Acta 2006, 51, 1330-1335.

18. Yuan, L.X.; Yuan, H.P.; Qiu, X.P.; Chen, L.Q.; Zhu, W.T. Improvement of cycle property of sulfur-coated multi-walled carbon nanotubes composite cathode for lithium/sulfur batteries. J. Power Sources 2009, 189, 1141-1146.

19. Chen, S.R.; Zhai, Y.P.; Xu, G.L.; Jiang, Y.X.; Zhao, D.Y.; Li, J.T.; Huang, L.; Sun, S.G. Ordered mesoporous carbon/sulfur nanocomposite of high performances as cathode for lithium-sulfur battery. Electrochem. Acta 2011, 56, 9549-9555.

20. Wang, J.; Chew, S.Y.; Zhao, Z.W.; Ashraf, S.; Wexler, D.; Chen, J.; Ng, S.H.; Chou, S.L.; Liu, H.K. Sulfur-mesoporous carbon composites in conjunction with a novel ionic liquid electrolyte for lithium rechargeable batteries. Carbon 2008, 46, 229-235.

21. Zhang, B.; Qin, X.; Li, G.R.; Gao, X.P. Enhancement of long stability of sulfur cathode by encapsulating sulfur into micropores of carbon spheres. Energy Environ. Sci. 2010, 3, 1531-1537.

22. Zhang, B.; Lai, C.; Zhou, Z.; Gao, X.P. Preparation and electrochemical properties of sulfur-acetylene black composites as cathode materials. Electrochim. Acta 2009, 54, 3708-3713.

23. Wang, H.L.; Yang, Y.; Liang, Y.Y.; Robinson, J.T.; Li, Y.G.; Jackson, A.; Cui, Y.; Dai, H.J. Graphene-wrapped sulfur particles as a rechargeable lithium-sulfur battery cathode material with high capacity and cycling stability. Nano Lett. 2011, 11, 2644-2647. 
24. Wang, J.L.; Yang, J.; Wan, C.R.; Du, K.; Xie, J.Y.; Xu, N.X. Sulfur composite cathode materials for rechargeable Lithium batteries. Adv. Funct. Mater. 2003, 13, 487-492.

25. Wang, J.; Chen, J.; Konstantinov, K.; Zhao, L.; Ng, S.H.; Wang, G.X.; Guo, Z.P.; Liu, H.K. Sulfur-polypyrrole composite positive electrode materials for rechargeable lithium batteries. Electrochim. Acta 2006, 51, 4634-4638.

26. Sun, M.M.; Zhang, S.C.; Jiang, T.; Zhang, L.; Yu, J.H. Nano-wire networks of sulfurpolypyrrole composite cathode materials for rechargeable lithium batteries. Electrochem. Commun 2008, 10, 1819-1822.

27. Liang, X.; Liu, Y.; Wen, Z.Y.; Huang, L.Z.; Wang, X.Y.; Zhang, H. A nano-structured and highly ordered polypyrrole-sulfur cathode for lithium-sulfur batteries. J. Power Sources 2011, 196, 6951-6955.

28. Zhang, Y.G.; Bakenov, Z.; Zhao, Y.; Konarov, A.; Doan, T.N.L.; Malik, M.; Paron, T.; Chen, P. One-step synthesis of branched sulfur/polypyrrole nanocomposite cathode for lithium rechargeable batteries. J. Power Sources 2012, 208, 1-8.

29. Liang, X.; Wen, Z.; Liu, Y.; Zhang, H.; Huang, L.; Jin, J. Highly dispersed sulfur in ordered mesoporous carbon sphere as a composite cathode for rechargeable polymer $\mathrm{Li} / \mathrm{S}$ battery. J. Power Sources 2011, 196, 3655-3658.

30. Mikhaylik, Y.V.; Akridge, J.R. Polysulfide shuttle study in the Li/S battery system. J. Electrochem. Soc. 2004, 151, A1969-A1976.

31. Liang, X.; Wen, Z.; Liu, Y.; Wu, M.; Jin, J.; Zhang, H.; Wu, X. Improved cycling performances of lithium sulfur batteries with $\mathrm{LiNO}_{3}{ }^{-}$modified electrolyte. J. Power Sources 2011, 196, 9839-9843.

32. Choi, J.W.; Kim, J.K.; Cheruvally, G.; Ahn, J.H.; Ahn, H.J.; Kim, K.W. Rechargeable lithium/sulfur battery with suitable mixed liquid electrolytes. Electrochimica. Acta 2007, 52, 2075-2082.

33. Chang, D.R.; Lee, S.H.; Kim, S.W.; Kim, H.T. Binary electrolyte based on tetra(ethylene glycol) dimethyl ether and 1,3-dioxolane for lithium-sulfur battery. J. Power Sources 2002, 112, 452-460.

34. Kim, S.; Jung, Y.; Park, S.J. Effects of imidazolium salts on discharge performance of rechargeable lithium-sulfur cells containing organic solvent electrolytes. J. Power Sources 2005, 152, 272-277.

35. Choi, J.W.; Cheruvally, G.; Kim, D.S.; Ahn, J.H.; Kim, K.W.; Ahn, H.J. Rechargeable lithium/sulfur battery with liquid electrolytes containing toluene as additive J. Power Sources 2008, 183, 441-445.

36. Stephan, A.M. Review on gel polymer electrolytes for lithium batteries. Eur. Polym. J. 2006, 42, 21-42.

37. Fenton, D.E.; Parker, J.M.; Wright, P.V. Complexes of alkali metal ions with poly(ethylene oxide). Polymer 1973, 14, 589.

38. Shriver, D.F.; Bruce, P.G. Solid State Electrochemistry; Cambridge University Press: Cambridge, UK, 1995; pp. 95.

39. Song, J.Y.; Wang, Y.Y.; Wan, C.C. Review of gel-type polymer electrolytes for lithium-ion batteries. J. Power Sources 1999, 77, 183-197.

40. Gray, F.M. Solid Polymer Electrolytes-Fundamentals and Technological Applications; VCH: New York, NY, USA, 1991.

41. Scrosati, B. Applications of Electroactive Polymers; Chapman Hall: London, UK, 1993.

42. Gray, F.M. Polymer Electrolytes; The Royal Society of Chemistry: Canterbury, UK, 1997. 
43. MacCallum, J.R.; Vincent, C.A. Polymer Electrolytes Reviews-I; Elsevier: London, UK, 1987.

44. MacCallum, J.R.; Vincent, C.A. Polymer Electrolytes Reviews-II; Elsevier: London, UK, 1989.

45. Idris, N.H.; Rahman, M.M.; Wang, J.Z.; Liu, H.K. Microporous gel polymer electrolytes for lithium rechargeable battery application. J. Power Sources 2012, 201, 294-300.

46. Kim, K.M.; Park, N.G.; Ryu, K.S.; Chang, S.H. Characteristics of PVdF-HFP/TiO 2 composite membrane electrolytes prepared by phase inversion and conventional casting methods. Electrochim. Acta 2006, 51, 5636-5644.

47. Weston, J.E.; Steele, B.C.H. Effects of inert fillers on the mechanical and electrochemical properties of lithium salt-poly(ethylene oxide) polymer electrolytes. Solid State Ionics 1982, 7, 75-79.

48. Jeon, B.H.; Yeon, J.H.; Kim, K.M.; Chung, I.J. Preparation and electrochemical properties of lithium-sulfur polymer batteries. J. Power Sources 2002, 109, 89-97.

49. Croce, F.; Persi, L.; Scrosati, B.; Serraino-Fiory, F.; Plichta, E.; Hendrickson, M.A. Role of the ceramic fillers in enhancing the transport properties of composite polymer electrolytes. Electrochim. Acta 2001, 46, 2457-2461.

50. Dissanayake, M.A.K.L.; Jayathilake, P.A.R.D.; Bokalawela, R.S.P.; Albinsson, I.; Mellander, B.E. Effect of concentration and grain size of alumina filler on the ionic conductivity enhancement of the $(\mathrm{PEO})_{9} \mathrm{LiCF}_{3} \mathrm{SO}_{3}: \mathrm{Al}_{2} \mathrm{O}_{3}$ composite polymer electrolyte. J. Power Sources 2003, 119-121, 409-414.

51. Ahn, J.H.; Wang, G.X.; Liu, H.K.; Dou, S.X. Nanoparticle-dispersed PEO polymer electrolytes for Li batteries. J. Power Sources 2003, 119-121, 422-426.

52. Appetecchi, G.B.; Croce, F.; Persi, L.; Ronci, F.; Scrosati, B. Transport and interfacial properties of composite polymer electrolyte. Electrochim. Acta 2000, 45, 1481-1490.

53. Jayathilake, P.A.R.D.; Dissanayake, M.A.K.L.; Albinsson, I.; Mellander, B.E. Effect of nano-porous $\mathrm{Al}_{2} \mathrm{O}_{3}$ on thermal, dielectric and transport properties of the (PEO) ${ }_{9}$ LiTFSI polymer electrolyte system. Electrochim. Acta 2002, 47, 3257-3268.

54. Lin, C.W.; Hung, C.L.; Venkateswarlu, M.; Hwang, B.J. Influence of $\mathrm{TiO}_{2}$ nano-particles on the transport properties of composite polymer electrolyte for lithium-ion batteries. J. Power Sources 2005, 146, 397-401.

55. Xi, J.; Qiu, X.; Ma, X.; Cui, M.; Yang, J.; Tang, X.; Zhu, W.; Chen, L. Composite polymer electrolyte doped with mesoporous silica SBA-15 for lithium polymer battery. Solid State Ionics 2005, 176, 1249-1260.

56. Chung, S.H.; Wang, Y.; Persi, L.; Croce, F.; Greenbaum, S.G.; Scrosati, B.; Plichta, E. Enhancement of ion transport in polymer electrolytes by addition of nanoscale inorganic oxides. J. Power Sources 2001, 97-98, 644-648.

57. Croce, F.; Settimi, L.; Scrosati, B. Superacid $\mathrm{ZrO}_{2}$-added, composite polymer electrolytes with improved transport properties. Electrochem. Commun. 2006, 8, 364-368.

58. Shin, J.H.; Kim, K.W.; Ahn, H.J.; Ahn, J.H. Electrochemical properties and interfacial stability of (PEO) ${ }_{10} \mathrm{LiCF}_{3} \mathrm{SO}_{3}-\mathrm{Ti}_{n} \mathrm{O}_{2 n-1}$ composite polymer electrolytes for lithium/sulfur battery. Mater. Sci. Eng. B 2002, 95, 148-156.

59. Jeong, S.S.; Lim, Y.T.; Choi, Y.J.; Cho, G.B.; Kim, K.W.; Ahn, H.J.; Cho, K.K. Electrochemical properties of lithium sulfur cells using PEO polymer electrolytes prepared under three different mixing conditions. J. Power Sources 2007, 174, 745-750. 
60. Zhu, X.; Wen, Z.; Gu, Z.; Lin, Z. Electrochemical characterization and performance improvement of lithium/sulfur polymer batteries. J. Power Sources 2005, 139, 269-273.

61. Agrawa, R.C.; Pandey, G.P. Solid polymer electrolytes: Material designing and all-solid-state battery applications: An overview. J. Phys. D Appl. Phys. 2008, 41, 223001.

62. Gray, F.M. Polymer Electrolytes: Fundamentals and Technological Applications; VCH: New York, NY, USA, 1991.

63. Wu, Y.P.; Zhang, H.P.; Wu, F.; Li, Z.H. Polymer Lithium-Ion Batteries; Chemical Industry Press: Beijing, China, 2007.

64. Xu, J.J.; Ye, H. Polymer gel electrolytes based on oligomeric polyether/cross-linked PMMA blends prepared via in situ polymerization. Electrochem. Commun. 2005, 7, 829-835.

65. Oliver, M. Blended Polymer Gel Electrolytes. U.S. Patent 5,658,685, 19 August 1997.

66. Hassoun, J.; Scrosati, B. A high-performance polymer tin sulfur lithium ion battery. Angew. Chem. Int. Ed. 2010, 49, 2371-2374.

67. Scrosati, B. Lithium polymer electrolytes. In Advances in Lithium Ion Batteries; Scrosati, S., Ed; Kluwer Academic/Plenum Publishers: New York, NY, USA, 2002; pp. 251-266.

68. Appetecchi, G.B.; Romagnoli, P.; Scrosati, B. Composite gel membranes: A new class of improved polymer electrolytes for lithium batteries. Electrochem. Commun. 2001, 3, 281-284.

69. MacDonald, J.R.; Barsoukov, E. Impedance Spectroscopy, Theory, Experiment and Applications, 2nd ed.; Wiley-Interscience: Hoboken, NJ, USA, 2005.

70. Liu, F.; Hashim, N.A.; Liu, Y.; Abed, M.R.M.; Li, K. Progress in the production and modification of PVDF membranes. J. Membrane Sci. 2011, 375, 1-27.

71. Watanabe, M.; Kanba, M.; Matsuda, H.; Mizoguchi, K.; Shinohara, I.; Tsuchida, E.; Tsunemi, K. High lithium ionic conductivity of polymeric solid electrolytes. Makromol. Chem Rapid Commun. 1981, 2, 741-744.

72. Ryu, H.S.; Ahn, H.J.; Kim, K.W.; Ahn, J.H.; Lee, J.Y. Discharge process of Li/PVdF/S cells at room temperature. J. Power Sources 2006, 153, 360-364.

73. Stephan, A.M.; Nahm, K.S.; Kulandainathan, M.A.; Ravi, G.; Wilson, J. Poly(vinylidene fluoride-hexafluoropropylene) (PVdF-HFP) based composite electrolytes for lithium batteries. Eur. Polym. J. 2006, 42, 1728-1734.

74. Stephan, M.A.; Dale, T. Charge-discharge studies on a lithium cell composed of PVdF-HFP polymer membranes prepared by phase inversion technique with a nanocomposite cathode. J. Power Sources 2003, 119-121, 460-467.

75. Stephan, M.A.; Dale, T. Characterization of PVdF-HFP polymer membranes prepared by phase inversion technique I: Morphology and charge discharge studies. Electrochim. Acta 2003, 48, 2143-2148.

76. Shin, J.H.; Jung, S.S.; Kim, K.W.; Ahn, H.J. Preparation and characterization of plasticized polymer electrolytes based on the PVdF-HFP copolymer for lithium/sulfur battery. J. Mater. Sci. Mater. Electron. 2002, 13, 727-733.

77. Li, G.C.; Li, Z.H.; Zhang, P.; Zhang, H.P.; Wu, Y.P. Research on a gel polymer electrolyte for Li-ion batteries. Pure Appl. Chem. 2008, 80, 2553-2563.

(C) 2012 by the authors; licensee MDPI, Basel, Switzerland. This article is an open access article distributed under the terms and conditions of the Creative Commons Attribution license (http://creativecommons.org/licenses/by/3.0/). 